\title{
Subjective Responsibility of Spanish University Teachers: A qualitative pilot study
}

\author{
Veronika Pečivová
}

\begin{abstract}
Teacher subjective responsibility is a prominent component of teachers' professional identity. It has a great impact on teachers' attitudes to various aspects and ethical questions relating to their profession and thus infuences their performance.

Aims: The pilot study presented in this paper aimed to reveal the position of teacher subjective responsibility within the self-perceived identity of teachers and to find its relations to individual ingredients of teachers professional identity. The participants in our pilot study were four Spanish university teachers preparing future primary school teachers for their careers.

Methods: To gain a deeper insight into the teachers' perception of their subjective responsibility we opted for a qualitative design and conducted semi-structured interviews. Having chosen a phenomenological approach, we concentrated on the participants' understanding of their subjective responsibility and its effects. We focused on the teachers' self-perception and inquired about the path that had led them to their profession and also about their teaching experience, searching for links connecting these to their subjective responsibility.

Results: The research results demonstrate that our participants do feel responsible for a number of issues and they also reveal a particularly strong connection between teacher subjective responsibility and their commitment. The inquiry also indicated that commitment, closely interconnected with subjective responsibility, comes with a price, affecting the personal lives of the participants.

Conclusions: Although our preliminary findings are limited because of the small number of participants and the strategy of a single interview, we believe that we have taken the first steps to understanding teacher subjective responsibility regarding its position within the broader context of teachers' professional identity.
\end{abstract}

Keywords: teacher responsibility, teachers' professional identity, university teachers, commitment, teachers' professional ethics

"Interviewing has provided me with a deeper understanding of the issues, structures, processes, and policies that imbue participants' stories. ... Most important and almost always, interviewing continues to lead me to respect the participants, to relish the understanding that I gain from them, and to take pleasure in sharing their stories." (Seidman, 2006, p. 130) 


\section{INTRODUCTION}

Since they play a crucial role in the development of their students as professionals, university teachers of future teachers are significant figures. They have a chance to educate new generations of educators and thus their impact cannot be denied. Their approach, attitudes, and views on the teaching profession and the perception of their own teacher identity may affect and shape the views of their learners, which are likely to be reflected later in their own teaching.

An important part of teacher professional identity is teacher subjective responsibility, which can be defined as teachers' inner belief, subjective judgement about their personal influence on results of their learners (Mareš, Skalská, \& Kantorková, 1994 , p. 25). Previous research studies have dealt with different aspects of teacher subjective responsibility. Some authors have focused on levels (Guskey, 1981; Mareš et al., 1994; Lauermann \& Karabenick, 2013; Frumos, 2015; Dofková \& Zdráhal, 2018) or categories (Lauermann \& Karabenick, 2013; Daniels et al., 2017) of teacher subjective responsibility. Other studies have aimed to find a connection between teacher subjective responsibility and self-efficacy (Lauermann \& Karabenick, 2013; Matteucci \& Kopp, 2013; Frumos, 2015; Silverman, 2010) or the wellbeing of teachers (Matteucci, Guglielmi, \& Lauermann, 2017; Daniels et al., 2017).

However, less attention has been paid to teacher subjective responsibility from the perspective of teachers' professional identity. And while many studies have focused on the subjective responsibility of primary and secondary school teachers or teacher trainees, the subjective responsibility of university teachers has not been investigated by many researchers (Mareš et al., 1994). This paper presents findings from qualitative interviews conducted with four Spanish university teachers. The purpose of this study was to discover the self-perceived identity of the participants, with a focus on their subjective responsibility as a significant component of teachers' professional identity. In the semi-structured interviews, we inquired how our participants describe themselves as teachers, what their teaching profession means to them, how they understand it, and what they feel responsible for as teachers.

\section{TheORETICAL FRAMEWORK \\ AND EXISTING RESEARCH}

\section{Teacher subjective responsibility}

Besides the term teacher subjective responsibility, authors also use the terms self-responsibility (Guskey, 1981), teacher's perceived personal responsibility (Matteuci \& Kopp, 2013), or personal responsibility (Lauermann \& Karabenick, 2011, 2013; Daniels et al., 2017; Daniels, Poth, \& Goegan, 2018; Eren \& Çetin, 2018). Unlike the responsibility that is assigned, subjective responsibility is "a sense of internal obligation and commitment to produce or prevent designated outcomes or that these outcomes should have been 
produced or prevented" (Lauermann \& Karabenick, 2011, p. 127). Teacher subjective responsibility is not isolated and it interacts with other concepts; therefore it is often viewed and studied from a broader perspective. Lukášová (2015) views the internal responsibility of teachers as one of the components of their professional responsibility, which is related to their self-perception, identity, self-regulation, and autonomy in decision making, and also to their conscience. As it is also linked to motivation, Lauermann (2017, p. 172) claims that it "has a dual status as both a motivational antecedent of teachers' behaviours (...) and a key element of teachers' knowledge about their professional roles (...)." We can say that teacher subjective responsibility, though internal, resonates externally in teacher performance.

With a quantitative methodology prevailing over qualitative design, researchers have approached the concept of teacher subjective responsibility differently. Some studies focus only on levels of subjective responsibility for students and their results, while others try to find connections between teacher responsibility and other concepts.

Surveys based on Guskey's (1981) quantitative questionnaire RSA - The Responsibility for Student Achievement Questionnaire (Guskey, 1981; Frumos, 2015; Dofková \& Zdráhal, 2018) and its standardized versions (Kantorková \& Mareš, 1992; Mareš et al., 1994) have come to the conclusion that teachers rather strongly tend to assume responsibility for student success, while in the event of student failure they attribute the responsibility to the students. Researchers have come to similar findings, although the research was conducted in different countries and with different categories of teachers. Guskey (1981) focused on primary and secondary school teachers in the USA, Frumos (2015) concentrated on Italian in-service chemistry teachers, and the respondents of Dofková and Zdráhal (2018) were Czech pre-service primary school maths teachers. Kantorková and Mareš (1992) first conducted their research with Czech pre-service teachers and later with primary, secondary, and university teachers (Mareš et al., 1994).

Other researchers have investigated the relation between teacher subjective responsibility and self-efficacy using scale questionnaires (Lauermann \& Karabenick, 2013; Matteucci \& Kopp, 2013; Frumos, 2015). Lauermann and Karabenick (2013) focused on German pre-service teachers and American in-service teachers, Matteucci and Kopp (2013) on Italian secondary school teachers, and Frumos (2015) chose Italian chemistry teachers for her research. According to the findings of all the above studies, there is a positive connection between teacher subjective responsibility and self-efficacy; however, they are not equal.

Associations between teacher responsibility, teaching approaches, and the well-being of teachers have also been of interest to researchers (Matteucci et al., 2017; Daniels et al., 2017). Matteucci et al. (2017) investigated Italian secondary school teachers using scale questionnaires 
and their findings indicate positive connections. Teachers who believe they can influence students' outcomes and perceive their relationship with students positively are likely to assume responsibility for academic achievement and feel more satisfied with their profession. On the other hand, some studies indicate that a high sense of subjective responsibility in a broader sense may have a negative impact on teachers and eventually even lead to exhaustion and professional burnout (Daniels et al., 2017) and a lack of sleep and quality family time (Lauermann, 2014).

Yet it appears that teachers' sense of their own responsibility promotes positive effects. A qualitative research study that investigated the teacher subjective responsibility of US primary and secondary teachers was conducted by Lauermann (2014), who used a self-report survey and content analysis. Her findings reveal that responsibility is strongly motivational and affects teachers' effort, perseverance, and commitment to students.

The findings of the mixed-methods research study of Daniels et al. (2018) conducted with Canadian in-service teachers indicate a certain convergence and divergence. Results from the qualitative self-report questionnaires reveal that teachers feel responsible for student motivation; however, half the participants had a low score in the quantitative scale questionnaire survey. The authors believe that rather than this being an issue of experience, the quantitative measurement might be problematic.

On the basis of the conclusions of the studies presented above, it can be stated that the concept and research of teacher subjective responsibility can be transferred worldwide and that the investigation of both pre-service and in-service teachers at different levels of education, i.e. primary, secondary, and tertiary, is legitimate. Bearing in mind that qualitative and quantitative methods may lead to different findings, the challenge is to find new research approaches that will provide a deeper understanding of teacher subjective responsibility.

\section{Teacher identity}

Teacher identity may be understood as the foundation stone of the teaching profession. It reflects the essence of teachers' professional self and very much determines their individual perception of their role and consequently also their performance in class. An emotional attachment to the role means that it becomes part of an individual and thus affects his or her life (Akkerman \& Meier, 2011).

Authors define teacher identity as the formation of an adequate perception of oneself as a teacher (Lukas, 2007) or as self-awareness in the teaching profession, while a teacher's professional self is based on basic attitudes, key relationships, values, and self-perception in the teaching profession (Lukášová, 2015). Rather than being viewed as isolated, teacher identity may be approached from a socio-cultural perspective, viewed from a wider context, which includes the attitudes of the society towards teachers. Moreover, teacher identity is constantly evolving and the 
social context is a crucial influence in its construction and formation (Lankveld et al., 2017; Akkerman \& Meier, 2011). Fostering professional identity is an incessant process of self-awareness of the substance of the profession and one's own professionalism (Lukášová, 2015). Professional identity is "shaped and reshaped in interaction with others in a professional context" (Beauchamp \& Thomas, 2009, p. 178) and it can be affected by critical incidents in one's career (Švaříček, 2011). Each teacher follows a unique path constructing their own identity and reflecting their individual self, experience, and both professional and personal conditions.

The identity of university teachers and its development differ in some aspects from the identity of primary and secondary teachers, because university teachers are also researchers (Šed'ová et al., 2016; Lankveld et al., 2017). Dealing with multiple roles comes with challenges and responsibilities that are not easy to face. This study deals with the teacher identity of university teachers from the perspective of their teacher subjective responsibility, aiming to reveal the links between the two concepts.

\section{Methodology}

Regarding its aim of presenting university teachers' perception of their professional identity and subjective responsibility, a phenomenological qualitative approach was used in this study and the method of semi-structured interviews was applied. The central research questions were:
1. How do the Spanish university teachers perceive their identity?

2. What do the Spanish university teachers feel responsible for as teachers?

3. What are the links between teacher subjective responsibility and the teacher identity of the Spanish university teachers? In order to answer our research questions, a set of guiding questions was designed within the interview framework:

1. Can you tell me something about your teaching experience?

2. How would you describe yourself as a teacher?

3. Why did you decide to become a teacher?

4. What is your relationship with your students like?

5. What do you feel responsible for as a teacher?

6. How do you feel about responsibility for students' results?

7. How do you feel about responsibility for students' motivation?

8. How does your profession influence your life?

\section{Context and participants}

The participants in the pilot study are four female Spanish university teachers. They were recruited by snowball sampling at the faculty of education of a Spanish public university.

All of them have acquired their PhD degree and are currently teaching primary school teacher trainees at the same Spanish university. Two of them focus on the didactics of English and the other two on the didactics of mathematics in primary 
education. All of them had had some sort of teaching experience prior to entering tertiary education. One participant is still teaching at a primary school.

To keep their anonymity, the names of the participants were changed. The pseudonyms given are: Laura, Susana, Isabela, and Blanca.

Laura is a Spanish female university teacher with almost 30 years of teaching experience. She started her career as an English language teacher at primary and then at secondary school. She has been teaching at the university for 22 years since she began her PhD studies focusing on the didactics and methodology of English. Her students and mentees were primary and secondary school teacher trainees; for the last 11 years she has focused only on future primary school teachers.

Susana is a Spanish female university and primary school teacher with 30 years of teaching experience. She was mainly teaching English at preschool, primary, and lower secondary school and only started to teach primary school teacher trainees at the university a few years ago. Her subjects deal with the didactics and methodology of English in primary education.

Isabela is a Spanish female university teacher with 17 years of teaching experience, including six years at university. Her educational field is mathematics and the didactics of mathematics. At the beginning of her teaching career she was a secondary school teacher for four years; then she opened her own private school offering lessons in various subjects and finally, after finishing her $\mathrm{PhD}$ studies, she started to teach the didactics of mathematics in the tertiary education sphere.

Blanca is a Spanish female university teacher with four years of teaching experience at a public university and also at a private one, focusing on the didactics of mathematics in primary education. She formerly worked in a private company providing employee training.

\section{Data collection and analysis}

The data was collected during my twoweek academic mobility visit to a Spanish university, which had been planned with the objective of conducting the interviews. It was the second time I had visited the university and I already knew two of the participants - Susana and Laura, who kindly asked her two colleagues - Isabela and Blanca - to participate in the research and they agreed. I also had the opportunity to observe the classes of all the participants first, so none of them was a stranger to me when we met for the interviews.

Three interviews were conducted with the four participants; the shortest interview lasted 24 minutes and the longest one 50 minutes. Two of the participants (Laura and Susana) agreed to be interviewed individually in English because they are proficient English users and they teach their subjects in English. The other two participants (Isabela and Blanca) preferred to give the interview together as they consider themselves a team and they feel comfortable supporting each other. They preferred to give the interview in 
Spanish as they felt more confident answering and they believed their answers would be more natural and accurate. The interviews with Susana, Isabela, and Blanca were conducted in their offices, while Laura was interviewed in a rented apartment where I was staying during my mobility visit. Since Isabela and Blanca share their office with another colleague, the interview was occasionally interrupted when he entered and left the office but we managed to continue without major difficulties.

As for the data analysis, the method of hematic analysis was used to analyse the interview data. The recorded semi-structured interviews were first transcribed and then coded. Subsequently, core categories were identified and finally the following four main themes emerged: self-perception of one's own teacher identity, motivation for choosing the teaching profession, teacher subjective responsibility, and the cost of commitment.

\section{Results}

In the following section the four main themes are presented and discussed, providing the individual views of each participant.

\section{Self-perception of one's own teacher identity}

When defining themselves as teachers, all the participants first described themselves, their teaching style, and professional approach to teaching and also included aspects related to their students. Especially Laura, Isabela, and Blanca stress the importance of incessant professional growth and continuous learning. Although they did not say so explicitly, they are committed teachers. Their answers and comments carry this message very strongly.

Laura sees herself mainly as passionate and enthusiastic and supports her selfperception with her students' words “... they say about me and they say you are so enthusiastic, it is impossible to get bored in your class, 'cause you're different." She attributes these features of herself as a teacher to the love she feels for her profession: "I am enthusiastic and I'm passionate because I love what I do."

She also sees herself as very motivated, systematic, and analytical and indirectly contrasts herself with teachers who are "extremely passive" in their classes, often "disconnected from their students", and complain about students' lack of motivation. Laura tries to be approachable and open to her students, while setting certain boundaries. She stresses the importance of communication in the class because "the teacher is not an island in the class".

She completely embraces her teacher identity; she is a teacher through and through: "I' $m$ altogether a teacher whether I am at the university or whether I'm going for a walk." In other words, her personal identity and her professional identity are intertwined. Laura also believes that never-ending professional growth and learning from her own students is crucial: "I think that's certainly the most valuable aspect about be- 
ing a teacher; never stop learning, never stop approaching your students, and never stop learning from your students."

Laura views her role in students' life as crucial: "I'm absolutely convinced that teachers have a lot to do in the life of students and when I say life, I mean life and not just academic subjects." For her the teacher is an educator whose duties go beyond knowledge transfer and who feels an urge to make students better people and thus facilitate learning, leading to a change in students as human beings.

Susana's reflection of her identity as a teacher is not very detailed. She describes herself as a creative and passionate teacher and rather provides her characteristics through her goals in her classes. She says she is creative in order to avoid routine and to make students enjoy her classes. Susana believes that through being a teacher, she can stir positive emotions and show opportunities to her learners: "you make your students love the language, the new language, so what I think I'm doing is just making them think that there is a big window that they can open and they can see more things."

Isabela describes both herself and also Blanca as empathetic and innovative teachers. Blanca views herself as an eternal apprentice (aprendiz eterna), as a sponge (esponja) absorbing new things all the time. Isabela and Blanca agreed that sometimes they are too empathetic and helpful when dealing with their students. This constant innovation and neverending learning discussed by Isabela and Blanca corresponds with Laura's ideas about incessant professional growth. All the participants share an open attitude towards their students.

What Blanca and Isabela also consider important is being a part of a team and sharing ideas with their colleagues. This approach is in fact very much reflected in their request to be interviewed together. On the contrary, Laura and Susana rather view their profession as individual.

\section{Motivation for choosing the teaching profession}

Except for Blanca, all the participants were sure they wanted to become teachers and they never doubted their decisions. However, Blanca's motivation to become a teacher must have been at least as strong as the motivation of the other participants because she discovered her calling and started to study education much later in her life than her colleagues and had to overcome certain challenges. She had a baby during her $\mathrm{PhD}$ studies but managed to obtain the degree, so her motives were very strong.

Laura never doubted she wanted to be a teacher because her goal was to change the world. "Oh! I was absolutely sure I wanted to be a teacher. When I was younger, my own definition of being motivated to be a teacher was that (...) I thought that I needed to change the world so my contribution to this making the world a bit better was by... let's say fostering, inculcating values in students and I wanted students not just to be told that things are a certain way, I wanted the students to be engaged." 
Obviously, there is a moral imperative in her motivation and also in her attitude towards the teaching profession. This message about the importance of values is also reflected in Laura's perception of learning, which for her is more than passive memorizing of facts. According to her, to learn means to become a better person and she wants to make her students aware of this.

Isabela believes that teaching is in her blood, because her mother and also her grandmother had been teachers and the transmission of the profession from one generation to another is something genetic. Her daughter already knows she wants to become a teacher too.

Although Blanca's mother is a teacher too, she rejected the idea of becoming a teacher when she was younger. Being a rebel and a feminist, she studied engineering instead. However, after 12 years working for a construction company, she realized that she enjoyed providing employee training more than anything else and that teaching was her true calling. Therefore, she decided to study secondary teacher education and then obtained a PhD degree in education.

Isabela and Blanca share the view that teaching is a vocation and a journey to follow. For both of them maternity plays a key role in their profession. Not only do they see a connection between their choice of profession and their mothers, but being mothers themselves is a strong source of motivation for them. Keeping their children in mind, they want to promote changes in the contemporary education system through innovations in teaching future teachers.
When choosing her career, Susana was sure she wanted to be a teacher because she loved children; for her it was a vocation. Moreover, shortly after the interview, Susana sent a text message saying that she wanted to become a teacher to make the world better.

In their motivation, all the participants share the intention of making positive changes in society. Clearly, they believe that being a teacher goes beyond the mere transmission of knowledge and they verbalize that. The decision to become a teacher and to embrace the identity of a teacher was not purely rational but it has to do with the values of the participants and involves strong emotions.

\section{Teacher subjective}

\section{RESPONSIBILITY}

"...for me a teacher is the one who is aware that he has a responsibility for everything that happens in class..." (Laura)

As teachers, our participants feel responsible for a number of elements. Within the theme of teacher subjective responsibility, the main categories identified are:

\section{Responsibility for students' motivation}

Although each participant views her responsibility for the motivation of students slightly differently, they all agree they are responsible.

Laura feels totally responsible for students' motivation and engagement: “...it is your responsibility to make the students 
feel $O K$, motivated, interested, and engaged in class."

She also explains the importance of seeing things from students' perspective and creating an effective class.

While for Isabela, teachers' responsibility is to discover what motivates their students, Blanca says that more than the responsibility to motivate, she has the responsibility not to bore and the responsibility not to diminish students' motivation.

Susana accepts a good deal of responsibility for the motivation of students, which, in her view, can be encouraged by creating a positive learning environment in classes. "So, if you try, as a teacher if you try to make your class a motivating environment, it's like a microcosmos where you can enjoy yourself while learning, so I suppose students' motivation is going to increase...."

The attitude of the participants towards their responsibility for students' motivation demonstrates that their teaching is learner-centred and that they perceive motivation as a key element in the learning process.

\section{Responsibility for students' learning}

In this category Laura, Isabela, and Blanca talk particularly about their responsibility to promote students' responsibility for their own learning. Their aim is to encourage their students to become autonomous learners, "to engage students in their own process of learning" (Laura). According to Blanca, the teacher's job in this process is to "plant seeds" and make students responsible. Susana believes that in students' learning the teacher and the student share the responsibility.

Regarding the teacher's role in students' learning, Laura says: "And as a teacher your role is to help, to accompany, to facilitate the learning, not just to give information, you are not a dictionary or encyclopaedia." This view of a teacher as a facilitator, shared by Isabela and Blanca, reflects their understanding of learning.

With regard to attribution of the responsibility for students' results, they are more careful and they share the view that both teachers and students are responsible.

\section{Responsibility for (the relation- ship with) students}

For all the participants their relationships with their students are crucial. In fact, according to Laura, the highest responsibility, absolutely the most important, is relationships.

“... let's say if, for example you $x$-ray, let's see an $x$-ray of responsibility, everything you can see, probably for me the most important, absolutely the most important, remarkably important aspects would be everything that has to do with the personal relationship, because that's unique..." (Laura)

Isabela and Blanca consider it important to have an equal relationship with their students. Isabela claims they are "in the same boat", which sometimes makes her too engaged personally and emotionally. 
Susana says that students must feel they are important for the teacher and admits that she helps her primary learners with their personal problems.

\section{Cost OF COMMITMENT}

Although Laura, Isabela, and Blanca say their profession makes them happy, they admit that there is a price they are paying for being such committed teachers. Only Susana does not feel that being a teacher takes its toll on her personal life. However, she admits that in her private life she is still connected to her pupils, associating everyday life situations with her classes.

Laura acknowledges that the professional choices she made at the beginning of her career, dedicating even her free time to teaching and research, affected her private life considerably. Nevertheless, teaching is very rewarding for her and she speaks about the happiness and fulfilment she finds in her profession.

Blanca and Isabela claim there is an emotional and personal price for being committed teachers. They have small children and both of them feel there is an internal conflict between their roles as mothers and teachers. On the other hand, their own children are their motivation to do their best as teachers. The paradox is that although their children are the motivation for work, they do not receive the positive results.

"I'm doing it because of her but not for her and without her." (Blanca, author's translation from Spanish).
Being committed, both admit that they do more than they have to; for example, Isabela modified her evaluation system or brought all the pupils from her daughter's school to the university and arranged a workshop with teacher trainees. Blanca and Isabela also speak about the pressure to do research, which is stressful and affects their motivation. Blanca says that she prefers "to do" than "to tell". Their reactions indicate that they identify with the role of a teacher rather than a researcher.

\section{Discussion}

The analysis of the interview data revealed that although our participants have different levels of experience and their professional histories also differ, their attitudes have a lot in common. Except for Blanca, all the participants were convinced they wanted to become teachers when deciding about their careers. Obviously, for all the participants teaching is rather a calling than a job. They embrace their teacher identity and also attribute responsibility for a number of categories to themselves. All the teachers who were interviewed are learner-centred and perceive their professional identity within the context of the class and relationships with their students, which also seems to shape their perception of teacher responsibility. They are motivated to feel responsible and their responsibility motivates them to grow professionally, to keep learning and improving their teaching. The motivational element of teacher responsibility, 
which encourages teachers to act in a certain way, has already been demonstrated in previous research (Silverman, 2010; Lauermann, 2014). Isabela claims that responsibility and motivation should be balanced, because too much responsibility may reduce motivation. In the case of Isabela and Blanca sharing responsibility and getting support from their colleagues seems to be a significant helpful factor.

Towards the end of the interview Blanca and Isabela became very emotional, especially when talking about their children and the price they pay for being committed to their profession. After the interview they concluded that having released their thoughts and feelings was a kind of therapy for them. I believe that the fact they shared the interview experience emphasized their enthusiasm, which was present in their answers, and encouraged them to be open. Laura also expressed emotions acknowledging that although she had no regrets, through having given priority to her profession and being so devoted to it she had missed out on certain things in her personal life. This very much echoes the idea that an emotional attachment to the role of a teacher makes it a part of an individual and has a significant impact on his or her life (Akkerman \& Meier, 2011).

The findings of this study and of other authors imply that this impact on private life may be not only positive but also negative. A sense of one's own responsibility may encourage teachers to have an active attitude towards teaching and it is also connected with professional satisfaction (Matteucci et al., 2017). On the other hand, feeling highly responsible for many aspects is likely to deprive teachers of personal time (Lauermann, 2014) and to exhaust them (Daniels et al., 2017). It seems that the need for balance is another significant factor related to teacher identity.

\section{Conclusion}

The aim of this paper was to reveal how prominent teacher subjective responsibility is within teacher identity and in what way these concepts are linked. The data analysis has shown that the participants assume considerable responsibility for a number of aspects and they have a clear view of their identity. As the four teachers confirm, their commitment, motivation to do their best, and the responsibility they subjectively feel are related. In compliance with existing research, the findings of this paper indicate that teacher identity is a mix of many concepts and aspects and it is shaped by individuals themselves and also by the social context around them (Lankveld et al., 2017; Akkerman \& Meier, 2011). This professional self is like a "cocktail" in which teacher subjective responsibility is one of the main ingredients.

It should be noted, though, that the present pilot study has its limitations. The number of participants is not high; therefore we cannot draw general conclusions. Moreover, identity is something which is not fixed but rather changes with time and context (Akkerman \& Meijer, 2011) and also because teacher subjective responsibility is likely to change, the study 
presents the views of the four university teachers only at a given point of their careers. The length of each interview was different and perhaps not sufficient, and therefore a three-interview model (Seidman, 2006) with more elaborate guiding questions might be a suitable approach to apply in future research.

The pilot study, however, provides relevant individual perspectives. In the four cases we can see that teacher subjective responsibility, teacher professional identity, and commitment are connected and intertwined and that a focus on students is also a relevant aspect of subjective responsibility and teacher identity. Each interview provides an understanding of the participants' professional self-image, their own understanding of the teacher's role, the emotions and enthusiasm they are willing to invest, and their devotion to teaching.

\section{REFERENCES}

Akkerman, S. F., \& Meijer, P. C. (2011). A dialogical approach to conceptualizing teacher identity. Teaching and Teacher Education, 27, 308-319.

Beauchamp, C., \& Thomas, L. (2009). Understanding teacher identity: An overview of issues in the literature and implications for teacher education. Cambridge Journal of Education, 39(2), 175-189.

Daniels, L. M., et al. (2017). Combinations of personal responsibility: Differences in preservice and practicing teachers' efficacy, engagement, classroom goal structures and wellbeing. Frontiers in Psychology, 8, 906.

Daniels, L., Poth, C., \& Goegan, L. D. (2018). Enhancing our understanding of teachers' personal responsibility for student motivation: A mixed methods study. Frontiers in Education, 3, 91.

Dofková, R., \& Zdráhal, T. (2018). The responsibility for student's achievement applied to pre-service elementary school math teachers. INTED2018 Proceedings, 1387-1394.

Eren, A, \& Çetin, G. (2018). Pre-service teachers' beliefs about the teaching profession, curriculum orientations, and personal responsibility. Curriculum Perspectives, 39(1), 19-32.

Frumos, L. (2015). Teachers' sense of efficacy and responsibility for students' outcomes. Journal of Innovation in Psychology, Education and Didactics, 19(2), 255-262.

Guskey, T. R. (1981). Measurement of the responsibility teachers assume for academic successes and failures in the classroom. Journal of Teacher Education, 32(3), 44-55.

Kantorková, H., \& Mareš, J. (1992). Subjektivní odpovědnost studentů učitelství za žákovské výsledky [Subjective responsibility of student teacher for pupil achievement]. In V. Krejčí (ed.), Sborník praci Ostravské univerzity: Psychologie, pedagogika, tělesná výchova [Proceedings of the University of Ostrava: Psychology, pedagogy, physical education]. University of Ostrava.

Lankveld, T., Shoonenboom, J., Volman, M, Croiset, G., \& Beishuizen, J. (2017). Developing a teacher identity in the university context: A systematic review of the literature. Higher Education Research \& Development, 36(2), 325-342. 
Lauermann, F. (2014). Teacher responsibility from the teacher's perspective. International Journal of Educational Research, 65, 75-89.

Lauermann, F. (2017). Teacher motivation, responsibility, pedagogical knowledge and professionalism: A new era for research. In S. Guerriero (ed.), Pedagogical knowledge and the changing nature of the teaching profession (p. 172). OECD.

Lauermann, F., \& Karabenick, S. A. (2011). Taking teacher responsibility into account (ability): Explicating its multiple components and theoretical status. Educational Psychologist, 46(2), 122-140.

Lauermann, F., \& Karabenick, S. A. (2013). The meaning and measure of teachers' sense of responsibility for educational out comes. Teaching and Teacher Education, 30, 13-26.

Lukas, J. (2007). Vývoj učitele: přehled relevantních teorií a výzkumů [Teacher development: An overview of relevant theories and research]. Pedagogika, 57(4), 46-60.

Lukášová, H. (2015). Učitelské sebepojetí a jeho zkoumání [Teachers self-concept and its exploration]. Zlín: Tomas Bata University in Zlín, Faculty of Humanities.

Mareš, J., Skalská, H., \& Kantorková, H. (1994). Učitelova subjektivní odpovědnost za školní úspěšnost žáků [Teacher's subjective responsibility for school success of pupils]. Pedagogika, 44(1), 23-36.

Matteucci, M. C., Guglielmi, D., \& Lauermann, F. (2017). Teachers'sense of responsibility for educational outcomes and its associations with teachers' instructional approaches and professional wellbeing. Social Psychology of Education, 20, 257-298.

Matteucci, M. C., \& Kopp, B. (2013). “Do they feel responsible?” Antecedents of teachers' sense of responsibility. In Proceedings of $5^{\text {th }}$ International Conference on Education and New Learning Technologies. Barcelona, 5013-5017.

Seidman, I. (2006). Interviewing as qualitative research: A guide for researchers in education and the social sciences. New York: Teachers College Press.

Silverman, S. K. (2010). What is diversity? An inquiry into preservice teacher beliefs. American Educational Research Journal, 47(2), 292-329.

Šed’ová, K., et al. (2016). Pojetí výuky a profesní identita začínajících vysokoškolských učitelů [The concept of teaching and professional identity of beginning university teachers]. Studia paedagogica, 21(1), 9-34.

Švaříček, R. (2011). Critical incidents in forming the professional identity of the teacher. Pedagogika.sk, 2(4), 247-274.

Mgr. Veronika Pecivová

Tomas Bata University in Zlin, Faculty of Humanities, Language Centre;

e-mail:vpecivova@utb.cz 